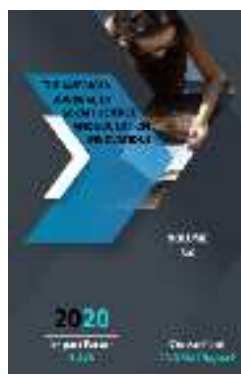

\title{
Recources Of Livestock In Tukistan In The Late XIX Century- Early XX Century: Comparative Analysis
}

\author{
Urmonov Ulugbek Adhamjonovich \\ Teacher Of Department Of History Of Uzbekistan, Fergana State University, Uzbekistan
}

Journal Website:

http://usajournalshub.c om/index,php/tajssei

Copyright: Original content from this work may be used under the terms of the creative commons attributes 4.0 licence.

\section{ABSTRACT}

In the late XIX - early XX century the recourses of livestock in the Turkistan is examined and analyzed comperatively. Author noted that periodical information, documentas of archive and statistics plays main role on studying field of livestock

\section{KEYWORDS}

Animal husbandry, karakul, periodicals, zakat, archives, fertilization points.

\section{INTRODUCTION}

In the late XIX - early XX century animal husbandry had main role in the daily life and economy of Turkistan. Today, there are several resources that gives information about problems and condition of animal husbandry during colonism. We could mention as resources archive documents, materials of periodic press and statistic information. In other sides, each kinds of resources presents data which is not given in other resources. In some case three kinds of recourse gives similar and close information to each other, in other case they contradict each other. That is why in the late XIX - early XX century it should be analyzed comparatively the resources in order to understand clearly.

The archive documents which gives information about animal husbandry originated from correspondence between administration of colony, that is why this resource plays important role to analyze the ideas belongs to this sphere. On the other side, the problems and difficulties of local stock- 
breeder during their action indicated with their petition and these sources are still saving in archive funds today. Through inputting these sources to scientific communication the problems that are appeared in the system could be shown.

Archive documents are differing with given information about amount of cattle in the late XIX - early XX century. It can be indicated as an example, the National Archives of Uzbekistan has a collection of materials on the historical processes in the administrative units of the period under study, which, together with information on other areas, can show the number of livestock in each region. In particular, one of archive funds collected the data about Tashkent city. In this accumilation, the data is given according to years about the number of live-stock's quantity and overall number of sold cattle[1].

It is known from archive documents, in this period the huge attantion was given to increase the amount of karakul sheep. In particular, archival sources include correspondence with the Turkestan Department of Land and State Property on the establishment of breeding points for the breeding of karakul sheep in various parts of the country. One of such correspondences is a letter sent by the Land and State Property Administration to the chief agronomists of the provinces on April 6, 1915. The letter addresses the issue of establishing fertilization points in Samarkand, Fergana and Caspian regions. In particular, it is instructed to establish a fertilization center at the Irisu cattle farm near Skobelev in Fergana region. [2]. Measures aimed at breeding this type of livestock are carried out in all regions of the country. For example, the Department of Land and State Property has appointed L.F., the organization's chief livestock specialist. Bezvuglom asks to go to the Zirabulak desert in Samarkand region and study the livestock situation there. In addition, he instructed to discuss with the agronomist of Samarkand region the issue of establishing a breeding point for the breeding of karakul sheep in this area. He asked Bezvuglom to visit the Emirate of Bukhara and find out the price of karakul sheep in the markets there. [3].

\section{MATERIALS AND METHODS}

Archive sources presents the data about exporting live-stock in this period. In particular, in archive funds there is a telegram about taking away the small hooved animals 225 wagon from Cental Asia Railway Station and 20 wagon from Kales railway station [4]. In addition, the export and import of livestock at these stations was checked for their absence of disease. According to data of archival sources, in January 1915 at Tashkent stations 2006 head of sheep were loaded on wagons and 107 head of sheep and cattle were unloaded from wagons. [5].

Turkestan periodicals provide important materials on animal husbandry, one of the most important sectors of the economy. In general, the Turkestan press provides interesting information about the role of livestock in the economic life of the country, the problems of development of this sector. [6]. In particular, information on the state of sheep and goat breeding, their types, problems in this area and ways to solve them [7].

Articles in the press point out that the population of the province mainly raises two types of sheep, the most common type of which is the sheep that have big buttock. According to the "Turkestanskie Vedomosti" newspaper, the number of sheep of this breed in Turkestan in 1909 was 13,264,000, and their number was sometimes reduced by people who did not want to pay taxes. [8]. The second type of sheep-breeding was karakul, and in 1909 it was acknowledged that their number in Turkestan reached 376,800.

Periodicals also provide extensive information on horse breeding, which is one of the most important areas of animal husbandry. In particular, as noted in the article by $G$. 
Arandarenko, this area of animal husbandry has been in crisis since Turkestan was invaded by the Russian Empire. The author points out that the state does not pay attention to this area at all, and explains that during the period was ruled by khans great importance was given to horse breeding, not only in economic life, but also in the military sphere. G. Arandarenko revealed a lot of information in this area as a result of informal conversations with local population. The author notes that in the last decade it had become difficult to find a good horse in the big cities of Turkestan, their price of which is 2-3 times more expensive than before [10].

\section{RESULT AND DISCUSSION}

In the field of horse breeding [12], the history of horse breeding in Turkestan, the types of horses, their quantity and quality have changed, and the reasons for this, as well as measures to improve the quality of horses in the country and its involvement in the Russian army. Classification of local horses, in particular, Kazakh horses, Karabayir, Turkmen horses, was given, and the interest of businessmen from foreign countries was emphasized. In 1913, a "free" horse was sold to Germany, and at an exhibition in Kiev in 1914, the Germans tried to buy such horses again. [13].

In 1903, the Turkestan regional newspaper reported that due to the expansion of cotton fields, fodder production in the Fergana region had become a difficult problem. As a result of the dominance of the cotton industry, the livestock sector was in crisis and the number of livestock decreased from year by year. Due to the lack of fodder for cattle, farmers were had to sell them in the winter and buy livestock in early spring. [14]. Similar views can be found in a number of articles in "Turkestanskie Vedomosti" [15]. In general, it can be observed that the press materials are also confirmed by archival documents, including archival data, which show that during this period the price of fodder crops increased by $100 \%$ and the price of livestock by $50 \%$. [16].

Official statistical reports of the late 19th and early 2oth centuries are another source of information on livestock in Turkestan. Typically, these official statistical reports are prepared by the administration of the Russian Empire and include mainly materials on the number of livestock in the country, their types, livestock taxes, and pasture use. This type of statistic has been provided regularly since the 1870 s, but these materials have not been conducted in the same way across all regions. Therefore, this source type provides more general information.

In the 1870 s, materials on the economy, social status and culture of the Turkestan region were started publishing. The collections of these materials also focus on the livestock sector. A collection of such materials published in 1873 states that the population of Turkestan had a large number of livestock. In particular, there were 6,000,000 sheep and 300,000 camels in the Syrdarya region. According to mentioned source, that year there were a total of 10 million head of livestock in Turkestan. Their main part considered as sheep. This statistic data was identified during collecting taxes from live-stock. According to the authors who collected this data, many herds grazed on large pastures during the tax collection period, and not all of them were included in this statistic. Therefore, they point out that the number of livestock in Turkestan is even higher [17].

In some collections of statistics, the number of livestock is given for a certain part of the Turkestan region. For example, in 1876, a collection of materials written on the territory of Turkestan provided information on the condition and quantity of livestock in Zarafshan district. According to this statistical collection, in 1876 there were a total of 189,888 head of livestock in Zarafshan district, from them of which 148,000 were sheep, 6,800 were horses, 18,480 were cattle, 10,800 were 
goats, 8 were camels and 5,800 were donkeys. [18].

Similar information is provided for Syrdarya region. The statistics of Syrdarya region reveals the role of livestock in the economic life of the local population, as well as the number and types of livestock. In particular, the general data on the livestock situation in the Syrdarya region in 1880-1885 first analyzed the role of livestock in the daily life of the population, and then provided information on the types and their number of livestock and their number. Livestock provided the population with basic foodstuffs such as milk and meat on the one side, and animal skins and wool on the other side helped to provide the population with clothing and shelter (utov). In addition, the population treated their livestock as the main material wealth of their lives and by selling them bought other products that they need in their daily lives. According to this source, in 1879 Turkestan became much drier, which led to difficulties in feeding livestock. As a result, in 1879-1880, a large number of livestock died in the Syrdarya region. According to these statistics, in 1885 there were a total of 3,036,200 number of livestock in the Syrdarya region. Most of them were sheep, in number 2,016,900 The number of horses, camels, goats and cattle was also significant, with 292,000 horses, 264,100 camels, 214,400 cattle and 220,100 goats. During this period, the average price of a horse in the Syrdarya region was 30 rubles, a camel 40 rubles, a cattle 15 rubles, a sheep and a goat 3 rubles. If we calculate the market price of livestock in the Syrdarya region, their total cost is $29,326,900$ rubles [19].

Some sources not only provide information about the livestock sector in Turkestan, but also about the history of the industry. Including, A. When Middendorf writes about animal husbandry in the Fergana region, he first briefly gives information on the history of animal husbandry there. The author describes the history of horses in Fergana in particular in close connection with historical processes. In addition, $A$. Middendorf describes the physical condition of horses and provides information on each horse type. Descriptions of this species are also given for large horned cattle and small hooved[20].

\section{CONCLUSION}

In summary, archival documents, periodicals and statistical reports provide important information on the state of livestock in Turkestan. While these types of sources often provide information that is close to each other, in some cases it provides contraducting material. In particular, in all types of sources there is information about the number of livestock in Turkestan in the late XIX - early XX centuries. This situation allows us to study this issue in more perfectly. Unlike archival sources, periodicals and official statistics describe the role of livestock in the economy and in the daily lives of the population. On the other hand, archival sources have shown changes in the livestock sector.

\section{REFERENCES}

1. Whig. On issues of Turkestan cattle breeding // TV. - 1910. - No. 235; Whig. Lack of fodder and livestock trade // TV. - 1910. No. 269; The scourge of Turkestan cattle breeding // TV. - 1910. - No. 284; Whig. On raising livestock breeding in Turkestan // TV. - 1911. - No. 33; E-hiv. About the need. development of livestock breeding in Turkestan // TV. - 1913. - No. 172; E-hiv. The well-being of our regional livestock breeding // TV. - 1914. - No. 209.

2. Arandarenko G. Cattle breeding in the Zaravshan valley // TV. - 1880. - No. 34,38, 46; 1881. - No. 2, 3, 8, 9, 10, 12; The fall of our sheep breeding // TV. - 1911. - No. 166; Procerus. Forgotten branch of our animal husbandry // TV. - 1912. - No. 166; Procerus. Breeding one valuable animal // TV. - 1912. No. 168; Skvortsov A. Sketch of sheep and goat breeding in Turkestan // TV. - 1912. - No. 200, 201, 204; E-hiv. Turkestan sheep at the 
all-Russian exhibition // TV. - 1912. - No. 262; E-hiv. Goat breeding // TV. - 1913. - No. 48; Ehiv. To the history of karakul breeding // TV. - 1914. - No. 232, 235.

3. Skvortsov A. Sketch of sheep and goat breeding in Turkestan // TV. - 1912. - No. 200.

4. Skvortsov A. Sketch of sheep and goat breeding in Turkestan // TV. - 1912. - No. 204.

5. Arandarenko G. Cattle breeding in the Zaravshan valley // TV. - 1881. - No. 8.

6. Arandarenko G. Cattle breeding in the Zaravshan valley // TV. - 1881. - No. 10.

7. V.K. About horse breeding in the Turkestan region // TV. - 1898. - No. 92, 93; Old horse breeder. About local horse breeding // TV. 1898. - No. 96; Kolosovsky V. About local horse breeding // TV. - 1899. - No. 2; Bronnikov N. Thoughts on horse breeding in the Turkestan region // TV. - 1901. - No. 78; A.K. On the issue of horse breeding in Central Asia // TV. - 1906. - No. 151; Maslov V.D. Modern horse breeding in Turkestan // TV. - 1908. - No. 95, 96; V.G. On raising horse breeding in Turkestan // TV. - 1910. - No. 72; E-hiv. A question at the congress about a riding horse in Turkestan // TV. - 1914. - No. 18, 21, 22; On the issue of improving horse breeding in the Turkestan Territory // TV. 1915. - No. 94.

8. Pyanovsky. Horse forces of Turkestan, as a reserve of the State horse breeding // TV. 1914. - No. 84.

9. Livestock in Fergana // Newspaper of Turkestan region.15. E-hiv. On the need to develop livestock breeding in Turkestan // TV. - 1913. - No. 172; S.K. Tasks of the state financial and economic policy in the Turkestan region // TV. - 1916. - No. 111.

10. About the state of cattle breeding in the Turkestan region. / Materials for statistics of the Turkestan Territory. St. Petersburg. 1873.S. 477 /

11. Materials for the Turkestan Territory. St. Petersburg. 1879.S. 338.

12. Syr-Darya region. St. Petersburg. 1887.S. 149-163.

13. Middendorf A. Essays on the Fergana Valley. St. Petersburg. 1882.S. 268-300 